\title{
Alcohol and Health: Social Evolution, Production and Control
}

\author{
Paul Durrington ${ }^{1 *}$ and Handrean Soran ${ }^{2}$ \\ ${ }^{1}$ Faculty of Biology, Medicine and Health, Division of Cardiovascular Sciences, University of Manchester, UK \\ ${ }^{2}$ Department of Endocrinology, Diabetes and Metabolism, Manchester Royal Infirmary, Manchester University NHS Foundation Trust, Manchester, UK
}

${ }^{\star}$ Corresponding author: Paul Durrington, Faculty of Biology, Medicine and Health, Division of Cardiovascular Sciences, University of Manchester, UK; E-mail: pdurrington@manchester.ac.uk

Received: December 01, 2021; Accepted: December 07, 2021; Published: December 15, 2021

\begin{abstract}
Alcohol drinking has been intrinsic to human social evolution certainly from the period when change from hunter-gather to farmer took place, which in many societies dates from 10,000 or more years ago. Throughout much of that time the risk of water-borne diseases such as enteric fever was such that there were undoubted health benefits to consumption of alcoholic beverages, such as mead, beer, cider and wine, in preference to contaminated water. Further benefit may also be that fermented drinks provided a means of storing food energy when preservation methods such as freezing had yet to be developed. These benefits were no longer critical once efficient sanitation and safe water supplies and food storage technologies had been developed from the mid-19 $9^{\text {th }}$ century. The study of fermentation has contributed enormously to medicine providing drugs or their precursors as diverse as antibiotics and statins. During human cultural evolution alcohol has frequently been a key part of religious and fertility rites and of social activities, such as feasting. However, the introduction of cheap, distilled, alcoholic drinks, such as gin, in the late $17^{\text {th }}$ century was damaging to society and in modern times evidence for any health advantages to drinking alcohol is lacking. The threshold consumption below which no harm can be observed is low or non-existent. Whereas prohibition can be effective in theocracies as demonstrated by transnational statistics on alcohol consumption, historically, attempts to enforce prohibition solely by legislation have generally been disastrous in non-sectarian societies. The scale of the industries producing alcohol is vast and many drinks, particularly wine are intimately ingrained into many cultures. Taxation is a traditional means of curbing excess consumption and there may be a case for banning certain types of alcoholic products and advertising, but draconian measures will lead to increased crime through illegal drinking and the misuse of other recreational drugs. It should not be assumed that lessons from the success in reducing smoking can be directly translated into limitation of alcohol use to improve health.
\end{abstract}

\section{Introduction}

Alcohol production and consumption has been a key element in human social evolution and acculturation, certainly since the late stone-age. Beliefs about whether this is beneficial or harmful to health both of individuals and societies have fluctuated throughout history. In adopting a rational policy towards alcohol use and abuse [1], it is essential to understand not just recently, but historically, how it has come to occupy such an important place in many civilisations and whether claims that it has some health-giving properties are likely to be true or is it simply an instrument of pleasure with the potential through over-indulgence to cause harm?

\section{History}

\section{Stone-Age}

There is a school of thought these days that we were healthier as hunter-gatherers. Most of human genetic evolution had occurred by the time we had reached that stage in our social evolution. The idea is thus that our metabolism is best suited to the diet and energy expenditure of a Stone Age man after which it has not changed much, if at all. Presumably the life of a hunter-gatherer involved collecting shellfish from the beach, catching the occasional animal and seasonally eating the odd nut, wild fruit or root [2]. Certainly this diet included no more than a trace of alcohol, but equally certainly it did not often include the five portions of 'fruit and veg' of the type we are now frequently advised to eat. The fruit and veg of the huntergatherer would have been the diminutive specimens, not the florid vegetables we eat today as the result of artificial selection (selective breeding). However, our hunter-gatherer ancestors, who it is claimed were so fit, lived in small, nomadic groups, which does have its advantages. They did not have to worry too much about sewage mixing with drinking water, if they were regularly on the move. Enteric fever became a major problem in the settled communities where farming developed from the end of the last ice age about 12,000 years ago. Successful farming depended on artificial selection to create cereal crops, vegetables, fruit and farm animals, leading eventually to the diet we have today, and to major changes in society, including the predilection for feasting. The major production of mead, wine and beer also probably began around 10,000 years ago with the development of apiaries and the cultivation of grapes and cereals. It would have been facilitated by the development of pottery vessels in the late Neolithic period (around 11000BC). Industrial alcohol production probably did not begin in Europe, but probably in Asia minor. 


\section{Impetus to Develop Production of Alcoholic Beverages}

Usually it is assumed that the intoxicant property of alcohol was the major inducement for its production, but there were clear health benefits in former times. Beverages, such as wine, were a means of storing food energy and thus contributed to the avoidance of starvation during the winter months. Importantly too, fermented alcoholic drinks provided a safe water supply and thus prevented enteric fever [3]. Typhoid and other water-borne causes of enteric fever were the commonest cause of death, killing half of the population even as late as the mid- $19^{\text {th }} \mathrm{C}$. Perhaps it is not surprising, therefore, that wine or beer even at breakfast, were widely consumed in preference to water well into Victorian times. Interestingly the temperance movement made little headway until the mid- $19^{\text {th }} \mathrm{C}$ when improvements in sanitation, as the result of advances in public health engineering and the allocation of civic funding for it, ensured a safe water supply [4]. Being teetotal was before that a risky business.

\section{Mead}

The discovery that fermentation could produce intoxication may have been made by early man after consuming rotting honey from bee colonies. Presumably, attempts to replicate its pleasing intoxicant effect led to deliberate fermentation of honey. Mead is probably therefore the earliest widely consumed alcoholic beverage [5]. Thus mead was the ambrosia of the ancient Greeks, but its production declined in the south of Europe and Asia Minor, when grapes were discovered as a more easily produced, more predictable source of sugar for alcohol production by fermentation. Bees are, however, ubiquitous. Thus, in the north, where vine fruits were less available, the popularity of mead continued. In Norse/Aryan mythology a draught of mead, delivered by beautiful, divine maidens, was the reward for warriors who reached Valhalla. Celtic mythology tells of a river of mead running through paradise, while Anglo-Saxon culture regaled mead as the bestower of immortality, poetry and knowledge. The word "honeymoon" comes from the ancient tradition of giving bridal couples a month's worth of mead to ensure a fruitful union

\section{Beer}

Grain cultivation from a variety of plants developed in many locations from $11000 \mathrm{BC}$ and so also did beer-making. In some ways the history of beer is more interesting than wine, because it was developed in many different civilisations and cultures widely separated geographically [6]. In antiquity beer would travel less well than wine. Thus, exchange of knowledge concerning its manufacture, may have been largely responsible for its spread. However, beerdrinking might also have developed in some cultures at a time before they were likely to receive migrants or travellers from beer-producing regions. Therefore, it is tempting to speculate that the discovery of beer occurs at a particular stage of social evolution concurrently or shortly after the development of cereal crops. Babylonian clay tablets from c $4300 \mathrm{BC}$ describe recipes for beer. Noah's provisions for the Ark included beer. Beer was a vital part of the Babylonian, Assyrian, Egyptian, Hebrew, Chinese, and Inca cultures. Different grains were used in different cultures: Africa used millet, maize and cassava, North America used persimmon (although agave was used in Mexico), South America used corn (although sweet potatoes were used in Brazil), Japan used rice to make sake, China used wheat to make samshu, other Asian cultures used sorghum, Russians used rye to make quass or kvass and Egyptians used barley and may have cultivated it strictly for brewing as it made poor bread.

\section{Cider}

The origins of cider are obscure. Apples are known to have been cultivated in the Nile delta as early as 1300 BC, but they may have been grown much earlier in China [7]. Cider was, however, a novelty to the Romans on their first visit to Britain in 55BC. Its production by the Normans (of Viking descent) was undoubtedly on an industrial scale by the time of their conquest of Britain in 1066. The Viking diaspora of which Normandy was part extended at various times from the $8^{\text {th }}$ to the $11^{\text {th }}$ century AD not only to the Atlantic and Baltic coasts of Europe, but also the Mediterranean and Black Sea coastal regions of Europe, North Africa and Asia minor [8]. However, the spread of cider was more limited until modern times. Currently, the UK has the world's highest per capita consumption, as well as its largest ciderproducing companies. Cider is also popular in some other European countries including Ireland and some regions of Portugal, France, and Spain. Germany also has its own types of cider, a particularly tart version known as apfelwein.

\section{Wine}

As early as $6000 \mathrm{BC}$ production there is evidence of wine production with the wild grapes (Vitis vinifera sylvestris) indigenous to the Transcaucasian region between the Black and Caspian Seas embodying parts of present day Turkey and Azerbajan (ancient Armenia), Georgia and Iran. The earliest cultivated grape seeds (Vitis vinifera vinifera) together with jars and other artefacts for bulk wine production dating to $4100 \mathrm{BC}$ were discovered in a cave in Armenia [911]. Trade in wine led to the spread of grape cultivars and wine-making knowledge and technology south to Mesopotamia (Iraq, Syria and Kuwait) and Phoenicia (coastal Syria and Lebanon) and west through Bulgaria and Macedonia to Greece. Sea-going Phoenician traders and the expansion of the Greek Empire extended the culture of wine more widely still. The cults of Bacchus and Dionysus incorporated wine into religious rites in the Greek world. Cleopatra (from the dynasty of Greek rulers of Egypt) is said by Pliny to have drunk a goblet of wine in which she had dissolved a priceless pearl to impress Mark Anthony by consuming the most extravagant tipple in history. The wine, itself, must not have travelled well: it must largely have deteriorated to vinegar to convert calcium carbonate to acetate [12]. Under Rome the transport of wine improved and viniculture spread throughout its empire as far as the south of England and Germany [13]. Improvements in ceramic and glass technology were crucial to this. With the collapse of Rome's control of its former empire, European wine production would have been seriously threatened had it not been for the expansion of the Catholic Church. The belief that red wine is the blood of the Gods goes back to a pre-Christian tradition, but its consumption and production by monastic orders was way beyond its role in the eucharist. The Benedictines followed by the Cistercians were the greatest wine producers. Many persisting aspects of viniculture derive from this 
period. Dom Perignon (1638-1715), a Benedictine monk introduced many blending techniques and preservation methods, including secondary fermentation in which wine was preserved by carbon dioxide under pressure and thus fizzed when its cork was released. This provided an alternative to fortification with higher proof spirits, such as brandy (see distillation) to permit wine to travel well as, for example port and sherry. Thus champagne joined port and brandy in British society. Wine was taken to Central and South America by the Conquistadors and vines brought from Spain and Portugal were introduced and cultivated by their monasteries in Mexico and much of South America including California, Argentina and Chile. Jan van Riebeeck, a Dutch ship's doctor who believed wine could cure scurvy introduced wine production to South Africa after taking vine cuttings to Cape Town. Vines for wine production were brought to Australia in the 1830's and to New Zealand at about the same time or possibly a few years earlier from collections of French grapes in English hot houses.

The artificial selection of grape vine variants with desirable distinctive characteristics for wine production has been practised for several thousand years. Cross-fertilising these with other varieties to create good wine-producing hybrid vines is, however, a tedious business with only a small proportion being homozygotes for all of the desirable characteristics and several generations reaching maturity might be necessary to confirm this. Therefore the practice was to graft the new vines on to rootstock of wild-type vines, thus circumventing the need for sexual reproduction. However, in the 1860's the wine industries of France were devastated by Phylloxera vastatrix, an aphid imported from North America [14]. In France this infestation caused withering and destruction of vine roots. The scarcity of wine in France led to an increase in the drinking of absinthe. Soon after the vine disease began the microbial cause was identified by JulesEmile Planchon, using microscopy and influenced by Louis Pasteur's work [15]. That the microbe was a stage in the metamorphosis of an aphid already known in North America, Daktulosphaira vitifoliae, and imported from there, was, however, not appreciated and his work was initially ignored. Although less devastating outside France, Phylloxera spread to Austro-Hungary, Germany, Spain, Italy, Portugal and Madeira. Eventually, Pasteur, himself, was put in charge of the investigation of the cause of vine disease (1885). His reputation had by then been built with his famous proof that fermentation was due to yeast microbes and his saving of the the French silk worm industry from the ravages of a microbial disease [16]. However, his attempts at a chemical (pesticide) approach to control the blight failed. Ironically North America proved to be both the cause and the remedy. The wild vines from there were relatively unaffected by Daktulosphaira vitifoliae. Thus grafting the old vines onto rootstock from American varieties in countries affected by Phylloxera provided the eventual solution . Pasteur, of course, went on to make many more contribution to organic chemistry, germ theory, antisepsis and immunisation.

\section{The Discovery of Distillation and the Production of Spirits}

The widespread abstinence current throughout the Arab Muslim world is a comparatively recent adoption. As Omar Kayyam (10481131) remarks to his lover, 'A book of verses underneath the bough, a flask of wine, a loaf of bread and thou..... The word 'alcohol' is derived from an Arabic word and it was Arab alchemists who separated it from wine. The most famous of these, Jābir ibn Hayyān (721-815), devised apparatus for distillation in the $8^{\text {th }}$ century [17]. Distillation permitted the production of spirits with much higher alcohol content than was possible by fermentation alone and the use of inferior ingredients and techniques for the initial fermentation, which prior to distillation would produce an undrinkable liquid. Not only was production thus cheap, but the product was more easily transported than wine and beer. It could be issued to armies and navies and sold to the multitudinous poor. Huge quantities of gin (barley malt), rum (sugar cane), scotch whiskey (barley malt), bourbon whiskey (corn, rye, wheat, barley malt), brandy (grapes and other fruits) and vodka (potatoes, cereals) were produced commercially by the $18^{\text {th }}$ century in Europe and countries with populations of European origin [18]. Drunkeness became rife: signs outside gin shops in the proletariat parts of London read, 'Drunk for a penny; dead drunk for two pennies; clean straw for nothing.

\section{Temperance: Taxation, Legislation and Religion}

In Britain, a series of parliamentary acts from 1729 onwards were required to ameliorate the gin craze. Historically, attempts to outlaw alcohol generally either for reasons of morality or to increase the industrial productivity of the nation's workforce have generally failed dismally. Taxation (excise duty) on the other hand has proved highly successful for governments. Alcohol was first taxed in 1643 and by 1713 had overtaken land tax as the government's main source of revenue [19]. Often the declared motivation for increases in excise duty was to pay for the armed forces. Issues of religion, improved health and providing a better society were not the main motivation, at least until the growth of the temperance movement. A policy of prohibition might not only make a political party unsuccessful electorally, but also cut off its major revenue source, should it achieve office. In Britain in 1914 a movement to prohibit alcohol supported by Lloyd George and King George $5^{\text {th }}$ failed to gain popular support, although a ban persisted in the Royal Household until the war ended in 1918 and licensing hours were introduced on the grounds that they would increase productivity. Tsar Nicolas $2^{\text {nd }}$ did succeed in banning alcohol in 1914 (ineffectively and with the loss of considerable revenue for his government) throughout his empire, a ban which persisted longer than he did, being cancelled by the Bolsheviks in 1925. In the USA prohibition was enacted as the $18^{\text {th }}$ amendment to the constitution in 1920, but was rescinded in 1933, not least due to the uncontrolled rise in crime that resulted. Many other nations have briefly attempted to abolish alcohol consumption including Iceland, Norway, Finland Australia and New Zealand. Currently most of the nations where alcohol is illegal are Muslim. Examples are Yemen, Saudi Arabia, Maldives, Kuwait, Iran, Brunei and Afghanistan. The Koran is clear that intoxication is irreligious. Although specific mention of alcohol is not made, the current generally accepted belief is that 'Whatever intoxicates in large quantities, a small quantity of it is forbidden. Thus, the consumption of alcohol is frowned upon in Muslim societies, even in those that have stopped short of a state ban. With the loss of European influence in such societies dramatic changes have occurred with Algeria being the most extreme example. Until independence 
from France in 1962 it was the world's largest exporter of wine, whereas today its production has dwindled to almost none [20]. Christian denominations vary greatly in the degree to which they denounce alcohol with the reformed churches, such as the Presbyterian, Quaker, Methodist and Baptist denominations at the forefront of abolition. The predominant religion undoubtedly influences national alcohol consumption (Table 1).

\section{Benefits Derived from Scientific and Technical Advances in Brewing}

Fermentation due to yeasts or bacteria in the gut is vital for our digestive system. Fermentation is also widely used in the production and storage of foods as diverse as bread, cheese, pickles, yoghurt, vegetables (eg kimchi), fish (surströmming) and, of course, alcoholic beverages. This form of food preservation largely exploits the preservative effects of ethanol, lactic acid, acetic acid and carbon dioxide produced during fermentation, but other chemicals can be produced, depending on the micro-organism chosen. Despite its wide use for many thousand years it was not generally accepted until the latter part of the $19^{\text {th }}$ century following the findings of Pasteur that fermentation is a metabolic process ( involving living microorganisms) that produces chemical changes in organic substrates through the action of enzymes [21]. As the range of organic compounds produced by fermentation was investigated, techniques employed in the

Table 1: Wine and alcohol consumed (litres of pure alcohol per person aged 15 or more years in 2016 or latest year for which figures were available) published by the World Health Organisation [1]. Data for selected countries are arranged in descending order of wine consumption. The difference between the sum of the wine and beer consumption is generally due to intake of spirits. Data from Spain may be influenced by its tourist industry.

\begin{tabular}{|l|c|c|c|}
\hline Country & $\begin{array}{c}\text { Alcohol } \\
\text { consumption }\end{array}$ & $\begin{array}{c}\text { Alcohol consumed } \\
\text { as wine }\end{array}$ & $\begin{array}{c}\text { Alcohol consumed } \\
\text { as beer }\end{array}$ \\
\hline Portugal & 12.3 & 7.5 & 3.2 \\
\hline France & 12.6 & 7.4 & 2.4 \\
\hline Italy & 7.5 & 4.9 & 1.9 \\
\hline Greece & 10.4 & 4.7 & 3.3 \\
\hline Belgium & 12.1 & 4.6 & 5.4 \\
\hline UK & 11.4 & 4.1 & 4.1 \\
\hline Australia & 10.6 & 3.9 & 4.2 \\
\hline Germany & 13.4 & 3.8 & 7.1 \\
\hline Austria & 11.6 & 3.7 & 6.1 \\
\hline Ireland & 13.0 & 3.6 & 6.1 \\
\hline New Zealand & 10.7 & 3.5 & 4.0 \\
\hline Netherlands & 8.7 & 3.1 & 4.2 \\
\hline Norway & 7.5 & 2.7 & 3.3 \\
\hline Canada & 8.9 & 2.2 & 4.0 \\
\hline USA & 9.8 & 1.8 & 4.6 \\
\hline Spain & 10.0 & 1.8 & 5.4 \\
\hline Russia & 7.2 & 1.5 & $<.6$ \\
\hline China & 5.7 & $<0.1$ & $<.5$ \\
\hline India & & $<0.02$ & \\
\hline Egypt, Kuwait, Pakistan, Iran & 5.5 & \\
\hline & & & \\
\hline
\end{tabular}

brewing and wine-making industries were modified for the large scale production of organic compounds otherwise difficult to synthesise in quantity. This received considerable impetus when Chaim Weizmann (the father of industrial fermentation and first president of Israel) working in Manchester scaled up the knowledge that Clostridium acetobutylium yielded acetone from starch. Many tons of acetone necessary for cordite production were thus manufactured in the First World War. For this, sanctioned by Churchill and Lloyd George, six British distilleries were requisitioned.

The availability of industrial techniques for bulk culture of selected naturally occurring micro-organisms has subsequently led to the manufacture of a huge range of therapeutic drugs from antibiotics to statins [22]. More recently, the creation of genetically modified organisms has extended the array therapeutic agents as diverse as recombinant proteins and monoclonal antibodies. Whatever the evils of alcohol, knowledge gained from its production continues to contribute hugely to advances in medicine. The benefits of alcohol consumption on the other hand are more questionable.

\section{Units of Alcohol}

Quantities of alcohol in medical reports can be confusing. Quite simply, 1 unit is equivalent to $10 \mathrm{ml}$ of pure alcohol. With this knowledge it is easy to convert the alcohol content shown as vol/vol on the label of wine (and other alcoholic beverages) to units. For example $12 \%$ alcohol means $12 \mathrm{ml}$ per $100 \mathrm{ml}$ of wine. Thus, a $750 \mathrm{ml}$ bottle contains $12 \times 750 \div 100=90 \mathrm{ml}$ or 9 units of alcohol.

\section{Alcohol and Health in Contemporary Times}

\section{Epidemiology}

Alcohol is currently largely viewed as a cause of ill health. The catalogue of woe resulting from heavy alcohol consumption is well known and includes loss of social inhibition beyond conviviality, accidents, recklessness, suicide, violence and other criminal behaviour, excessive sedation and inhalation of vomit, dependence, acute and chronic liver disease, acute and chronic pancreatitis, acute and chronic gastritis, carcinoma of the breast, liver, pancreas, oesophagus and intestine, encephalopathy, myopathy, neuropathy, gout, rhinophymoma, pseudo-Cushings syndrome, gonadal atrophy, hypertriglyceridaemia and teratogenicity. Heavy alcohol consumption is also a cause of excess cardiovascular mortality due to dysrhythmias, especially atrial fibrillation, but also ventricular dysrhythmias, cardiomyopathy and, often overlooked, it can be a major contributor to hypertension. So does alcohol have any health benefits nowadays? It could be argued, we should not ignore its role in simply making life more enjoyable as long as it adds to and does not detract from the quality of the life. As Dean Martin said, 'I'd hate to be a teetotaller. Imagine getting up in the morning and knowing that's as good as you're going to feel all day'.

Moreover, there has been an ongoing debate since the 1980's about whether moderate alcohol consumption is associated with lower rates of coronary heart disease than those in non-drinkers [23,24]. The relationship between alcohol consumption and mortality is J-shaped. This has been attributed by some to lower rates of coronary heart 
disease (CHD) in moderate drinkers than in abstainers [23] and by others to pre-existing disease prompting alcohol abstention [24]. Meta-analysis of prospective observational studies has revealed that the J-shaped relationship with CHD and all-cause mortality is a highly reproducible finding $[25,26]$. In the largest meta-analysis the effect of alcohol was associated with decreased likelihood of fatal and non-fatal myocardial infarction [26]. The risk of death from heart failure, stroke and non-cardiovascular disease increased with alcohol consumption so that overall the lowest mortality was associated with consumption of around $100 \mathrm{~g}$ per week (12.5 units) in both men and women. In a more recent study of over 80,000 Chinese industrial workers around $25 \mathrm{~g}$ per week (3.1 units) was associated with the lowest incidence of death [27]. Any benefit from alcohol thus seems to occur below currently recommended 'safe' limits (see later).

\section{Mendelian Randomisation}

Any association between moderate drinking and longer life expectancy could be because moderate drinkers are healthier than non-drinkers for reasons other than their alcohol consumption. This confounding might be because modest drinkers are, for example, likely to be restrained in other potentially unhealthy behaviours, perhaps smoking less, or they may be from a higher socioeconomic group, which is associated with better health. Statistical adjustment to allow for confounding is of limited validity.

Ideally, of course, cause and effect should be established by a randomised trial. This is what has been done to establish the clinical efficacy of drugs, such as a cholesterol- or blood pressure-lowering medication. Participants are randomly assigned to receive the active drug or to be controls often given placebo to blind the patient and the investigator as to whether treatment is active or not until the end of the trial. After a few years, the incidence of heart attacks and other clinical events in the active treatment and control groups is compared. This is impossible with alcohol. You can hardly expect drinkers to be assigned to the non-drinking control group and vice versa. The same dilemma faced investigators trying to persuade governments that smoking was unhealthy.

Mendelian randomisation is a development which has been hailed as in some cases providing a substitute for randomised clinical trials. If an element of the exposure to a risk factor is genetically determined and there are variants of that gene which have a predictable effect on its penetrance, then it is possible to test for causality by assessing whether the disease is associated with the gene variant(s) linked to the greatest exposure. The method relies on the assumption that the gene variant itself contributes causally to exposure and on the assumption that, during meiosis (gametogenesis), which one of each parent's pair of genes coding for a particular characteristic a gamete receives is random (a matter of chance). In the case of alcohol exposure two genes have been the subject of particular interest in determining alcohol consumption. One codes for alcohol dehydrogenase, which converts ethanol to acetaldehyde. The second is acetaldehyde dehydrogenase which metabolises the acetaldehyde. Acetaldehyde causes flushing, headaches and many of the features of a hangover. It has been reported that lower activity polymorphisms of alcohol dehydrogenase slow down the rate of formation of acetaldehyde and that high activity polymorphic variants of aldehyde dehydrogenase limit the rise in its circulating levels. Inheritance of genes coding for low activity alcohol dehydrogenase and for high activity aldehyde dehydrogenase is associated with greater alcohol consumption and with increased rates of alcoholism and binge-drinking [28,29]. Alcohol dehydrogenase activity increases in heavy drinkers. So, acquired factors make it unsuitable for a Mendelian randomisation study. However, aldehyde dehydrogenase gene variants associated with increased alcohol consumption have been frequently been examined in relation to disease outcomes in Mendelian randomisation studies [29-31]. No benefit from any degree of alcohol consumption has been reported in these investigations. However, it has been questioned whether this type of genetic polymorphism influences consumption sufficiently to categorise participants reliably [32]. Claims that they exclude a role for low as opposed to low to moderate alcohol consumption in preventing CHD are likely to be unfounded, but on the other hand conventional epidemiology does not prove modest consumption causes such protection.

\section{Causality and Plausibility}

\section{Alcohol in General}

There is a plethora of mechanisms both for harm and benefit from alcohol. Alcohol exerts its acute effects directly and by, acetaldehyde to which it is rapidly converted. Some chronic effects such as degeneration of cerebral tissue and oesophageal cancer and gastritis may be due to repeated direct exposure to these. The likelihood of complications may be enhanced by nutritional factors, such as thiamine deficiency (wet beri beri) and by toxins contained in the particular beverage.

Thus certain alcoholic beverages may once have given rise to particular syndromes in specific groups of drinkers such as Marchiofava Bignami syndrome in chianti drinkers [33], oesophageal carcinoma in calvados drinkers [34] and cardiomyopathy when cadmium was used in beer production [35]. On the positive front, effects of alcohol on risk factors known to cause coronary heart disease has been a popular topic for research [36]. Experimental evidence undoubtedly confirms that alcohol increases high density lipoprotein (HDL), which in many epidemiological studies is inversely associated with the incidence of atherosclerotic cardiovascular disease. Experimentally alcohol also decreases fibrinogen, the major cause of thrombosis which occurring on atheromatous arteries is the usual cause of heart attacks. One should be cautious in the interpretation of the effect of the alcoholinduced increase in HDL on atherosclerosis risk following the failure of cholesteryl ester transfer inhibitor drugs, which raise HDL far more than alcohol, to ameliorate atherosclerotic cardiovascular disease incidence [37]. Furthermore excess alcohol also causes triglyceride levels to rise. Although it has also been suggested that moderate alcohol consumption is associated with a decreased likelihood of developing type 2 Diabetes mellitus, that these are causally related has been questioned in a recent meta-analysis [38].

\section{Wine vs. Other Types of Alcoholic Beverage}

Wine has come to occupy a place of veneration amongst alcoholic beverages, perhaps because of its southern European connections, 
significance in Christian culture, association with class, aestheticism, high-living and chique. 'Wine is one of the most civilized things in the world and one of the most natural things of the world that has been brought to the greatest perfection, and it offers a greater range for enjoyment and appreciation than, possibly, any other purely sensory thing' (Ernest Hemingway. Death in the Afternoon). It has also since ancient times been recommended by certain physicians to improve health. Can something enjoyable be healthy? Physicians rarely recommend anything pleasurable as part of a healthier lifestyle is there reason to be more optimistic about at least some types of alcoholic beverages?

The effect of alcohol on biomarkers, such as HDL cholesterol and fibrinogen, is similar whatever the alcoholic beverage and seems to depend on the alcohol itself. However, the notion that wine, particularly red wine, may have more health-giving properties than other alcoholic drinks has been around for some while. The usual reason for advancing this hypothesis is the so-called French paradox: some parts of Southern Europe have relative freedom from coronary disease, despite in the case of the South of France, enjoying a relatively fatty diet [39]. Typical alcohol consumption is similar in France and Ireland with its much higher CHD incidence (Table 1). In France, however, wine comprises a much higher proportion of the alcohol consumed. Studies of people resident in Toulouse and in Belfast reveal that HDL is higher in Toulouse [40], but there is no evidence that wine has a greater effect on HDL than any other source of alcohol [39]. Thus other aspects of the French diet, such as olive oil, and genetic differences may have contributed to the higher HDL in Toulouse and its relatively low $\mathrm{CHD}$ incidence. However, there is no denying that the contribution of wine to the alcohol consumed in France, Portugal and Italy is higher than in the UK, Ireland and North America (Table 1) where coronary rates are substantially greater. Red wine has been the subject of most interest as protecting against CHD, because it contains copious quantities of polyphenolic flavonoids, which are potent antioxidants [39] However, randomised trials of antioxidant vitamins have been unsuccessful in preventing heart disease [41]. It could, nevertheless, be argued that antioxidant vitamins used in these trials are not the antioxidants in red wine. It is possible too that some other mechanism could mediate the postulated protective effect of flavonoids in red wine against atherothrombosis [42]. However, it has also been questioned whether these substances are absorbed from the intestine in sufficient quantity [43].

\section{J-Shaped Relationship with Mortality}

Why does the CHD benefit of alcohol disappear with higher consumption? In large part because it can lead to obesity, particularly the more dangerous central obesity (brewers' goitre) which is linked to high blood pressure, to deteriorating lipid levels and to diabetes [44]. Wiry alcoholics do not escape cardiovascular consequences, because excessive alcohol can directly damage the heart leading to dysrhythmias [45] and cardiomyopathy [46]. Furthermore, the fibrinogen-decreasing effect of alcohol may not be beneficial, if blood pressure also rises secondary to alcohol overindulgence, because it can cause strokes due to cerebral haemorrhage [47], Tom Sharpe's Porterhouse Blue effect.
Mortality from non-cardiovascular disease increases directly with alcohol consumption particularly chronic liver disease, chronic and acute pancreatitis and neoplastic disease (particularly oropharynx, oesophagus, stomach and pancreas, but also tissues less directly exposed such as colorectum and breast) [48].

\section{Safe Limits for Alcohol Consumption}

There is a dichotomy of views about whether advice to the public about health and alcohol should be to consume the quantity associated with the lowest mortality or to recommend an upper limit above which mortality exceeds the average. There is thus considerable variation in what are considered safe limits in different nations [49]. Logically, if there is an upper limit, there should be a lower limit. However, there is no national guidance to drink small amounts of alcohol rather than abstain.

The general health recommendation in the UK, which attempted to balance the benefits of alcohol against its ill-effects, was for men not to exceed 21 or women 14 units weekly. This is no more than one third of a bottle a day for men and rather less for women. Women, although less likely than men to become alcohol-dependent, are more susceptible to alcohol-related disease [50]. This seems to make sense because they generally have a smaller surface area and liver than men, but on the other hand they are more likely to underestimate their consumption, creating the impression that their health has been damaged at lower levels of intake. Recently 14 units weekly for both men and women has become the NHS recommendation. This was influenced by the Mendelian randomisation studies. In practice, a medical history should ideally contain information about individual alcohol intake to detect drinking likely to damage health [51], but whereas it is easy to tell a patient who smokes any tobacco product to stop, it is lengthy and complicated to discuss precise quantities of alcohol and may distract from other parts of the history about which it is necessary for the patient to be frank if alcohol intake is not germane to the main purpose of the consultation. Rather than record 'socially' or some such euphemism ('not enough' one lady told me) it is better in general to ask whether any alcohol is consumed in a typical week and if so how much in terms of pints of beer, glasses of wine etc, bearing in mind that 14 units is around 5 pints of beer or 5 glasses of wine per week.

\section{Prevention of Harmful Alcohol Consumption}

1. On present evidence it can be concluded beyond doubt that binge drinking is harmful. This particularly worrying when it is encouraged by the supply of cheap alcohol to young people.

2. That alcohol itself is the cause of decreased mortality in modest drinkers is unproven. On the other hand it cannot be said that it is harmful. Moderate consumption can contribute to the enjoyment of life.

3. Obviously, the medical profession should advise against regular drinking when it occurs at a level which may be harmful to health. To decide at what level this is the case is difficult.... 
4. The most effective means of limiting alcohol intake is on religious grounds enforced by government and by social stigmatisation (including informants to religious and state authorities). In societies which can worship freely this is clearly impossible.

5. Legally banning alcohol sales and manufacture has never proved successful and indeed may lead to serious crime.

6. Taxation has proved to be the most effective means of preventing inappropriate drinking.

7. Medical assistance such as provision for drying out, psychiatric support and Alcoholics Anonymous are clearly helpful in some individuals [52], but do not prevent excessive drinking in society as a whole to the detriment of health or the creation of addicts.

8. The information in this review invites comparison with another social addiction, namely smoking, which has declined greatly in recent times [53]. Both alcohol and smoking are widespread social addictions, but alcohol has been available for thousands of years longer in which time it has become intimately linked with culture and tradition and has in the past had health benefits, whereas cigarette smoking, the most harmful form, was a phenomenon largely of the $20^{\text {th }}$ century [54]. Alcohol is deeply ingrained into European culture and societies adopting European customs. The link between smoking even in moderation and carcinoma of the bronchus is strong, but on the other hand smoking does not cause disinhibition and inappropriate behaviour. Passive smoking and social stigmatisation has contributed greatly to the decline in smoking as has financial cost due to high taxation. The tobacco industry is huge and has responded by increasing its sales in Asia and by diversification. The alcohol industry is vast even compared to tobacco, but its opportunities to expand into markets in Asia are limited. Both industries have relied heavily on promotion including advertising and sponsorship. This has been limited much more in the case of smoking by legal restriction and by the adverse publicity which organisations accepting sponsorship might receive. Smoking has largely disappeared from films and television and tobacco sponsorship of sport or medical research is more likely to lead to disapprobation than promotional opportunity. Despite the opposition which would ensue from the public relations machine representing the alcohol industry, it might be possible to do more to prevent the promotion of drunkenness by bars, clubs and entertainment providers. Cheap alcoholic beverages are frequently used as loss leaders to entice shoppers: minimum pricing per unit of alcohol could prevent this practice.

9. A coherent policy must be one of limiting excessive drinking. Historically, it has come to be regarded as normal to over-indulge on certain social occasions. Initiation of the young into over-consumption can be reduced by taxation, discouragement of provision of cheap alcohol and by educational and professional bodies not including it as part of their ritual.

10. People can be persuaded to modify their habits when not only their own health, but that of others, is at risk. Potential harm from passive smoking undoubtedly was a major factor in banning smoking from public places. Young women are highly likely to give up both smoking and alcohol during preganancy. Driving and many types of work whist under the influence of alcohol are banned by legal and contractual restraints. Protecting the NHS has been a main plank of persuading people to avoid behaviour likely to spread COVID infection. Perhaps it should be more widely publicised that in at least a fifth of acute hospital admissions over-indulgence in alcohol is largely responsible [55].

11. To promote the message that all smoking is dangerous is probably easier than to promote moderation in alcohol. Advice to drink alcohol responsibly almost certainly requires more cooperation from the alcohol industry than banning smoking in public places did from the tobacco industry, but a clearer mutually acceptable definition of what is meant by responsible is required $[56,57]$.

\section{Conclusion}

What we can learn from epidemiology is more limited than is often claimed. More should be done to curb excessive drinking, which is both unpleasant and unhealthy. Abstinence can be encouraged, indeed legislated for, in certain limited circumstances, but an outright ban for the whole population can do more harm than good. Our current knowledge about alcohol and health can best be summarised in the words of Marie Lloyd, 'A little of what you fancy does you good'.

\section{Acknowledgment}

The authors acknowledge support from Lipid Disease Fund and The National Institute for Health Research/Welcome Trust Clinical Research Facility.

\section{References}

1. Global status report on alcohol and health 2018. Geneva: World Health Organisation. Licence CC BY-NC-SA 3.0 IGO.

2. Gibbons A. The evolution of diet. https://www.nationalgeographic.com/foodfeatures/ evolution-of-diet/

3. Basnyat B, Qamar FN, Rupali P, Ahmed T, Parry CM (2021) Enteric fever. BMJ 26: 372:n437. [crossref]

4. Wikepedia. Great stink. https://en.wikipedia.org/wiki/Great_Stink

5. Heritage Daily. History of mead. https://www.heritagedaily.com/2020/03/history-ofmead/126299

6. Smith G (1995) Beer: a history of suds and civilisation from Mesopotamia to microbreweries. London: Harper Collins.

7. Juniper BE, Mabberley DJ (2019) The extraordinary story of the apple. London: Kew Publishing.

8. Oliver N (2012) Vikings.London: Weidenfeld and Nicolson.

9. Barnard H, Dooley AN, Arashian G, Gasparyan B, Faull KF (2011) Chemical evidence for wine production around 4000BC in the Late Chalolithic Near Eastern highlands. J Arch Sci 38: 977-984. 
10. This $\mathrm{P}$, Lacombe T, Thomas MR (2006) Historical origins and genetic diversity of wine grapes. Trends in Genetics 22: S11-19. [crossref]

11. McGovern PE et al. (1996) Neolithic resinated wine. Nature 381: 480-481.

12. Bartowsky EJ, Henschke PA (2008) Acetic acid bacteria spoilage of bottled red wine -- a review. Int J Food Microbiol 125: 60-70. [crossref]

13. Lukacs P (2013) Inventing wine: a new history of one of the World's most ancient pleasures. New York: WW Norton and Co.

14. White K (2017) The Devastator: Phylloxera Vastatrix \& The Remaking of the World of Wine 2017.

15. Planchon JE (1875) Les vignes Americaines: Leur culture, leur resistance au Phylloxera et leur avenir en Europe. Montpelier: Academie des Sciences et Lettres.

16. Casco J (2017) Heroes of wine: Louis Pasteur (1822-1895) 2017.

17. Amir SS, Tbakhi A, Jabir ibn Hayyan (2007) Ann Saudi Med 27: 53-52.

18. Forsyth M (2017) A short history of drunkenness. London: Viking.

19. Yeomans, H orcid.org (2018) Taxation, State Formation and Governmentality: The Historical Development of Alcohol Excise Duties in England and Wales. Social Science History 42: 269-293.

20. Meloni G, Swinnen J (2014) The Rise and Fall of the World's Largest Wine ExporterAnd Its Institutional Legacy. Journal of Wine Economics 9: 3-33.

21. Schlenk F (1997) Early research on fermentation - a story of missed opportunities. In New Beer in an Old Bottle: Eduard Buchner and the Growth of Biochemical Knowledge, pp: 43-50, ed. A. Cornish-Bowden, Universitat de València, Spain.

22. Demain AI, Sanchez S (2009) Microbial drug discovery: 80 years of progress. $J$ Antibiot 62: 5-16. [crossref]

23. Pham JV et al (2019) A review of the microbial production of bioactive natural products and biologics. Front Microbiol.

24. Marmot MG, Rose G, Shipley MJ, Thomas BJ (1981) Alcohol and mortality: a U-shaped curve. Lancet 14: 580-583. [crossref]

25. Shaper AG, Wannamethee G, Walker M (1998) Alcohol and mortality in British men: explaining the U-shaped curve. Lancet 2: 1267-1273. [crossref]

26. Zhao J, Stockwell T, Roemer A, Naimi T, Chikritzhs T (2017) Alcohol Consumption and Mortality From Coronary Heart Disease: An Updated Meta-Analysis of Cohort Studies. J Stud Alcohol Drugs 78: 375-386. [crossref]

27. Wood AM, et al. (2018) Risk thresholds for alcohol consumption: combined analysis of individual-participant data for 599912 current drinkers in 83 prospective studies. Lancet 391: 1513-1523.

28. Zhang X, Liu Y, Li S, Lichtenstein AH, Chen S, et al. (2021) Alcohol consumption and risk of cardiovascular disease, cancer and mortality: a prospective cohort study. Nutr J 20: 13.

29. Quertemont E (2004) Genetic polymorphism in ethanol metabolism: acetaldehyde contribution to alcohol abuse and alcoholism. Molecular Psychiatry 9: 570-581. [crossref]

30. Edenberg HJ, Xuei X, Chen HJ, Tian H, Wetherill LF, et al. (2006) Association of alcohol dehydrogenase genes with alcohol dependence: a comprehensive analysis. Hum Mol Genet 15: 1539-1549. [crossref]

31. Chikritzhs TN, Naimi TS, Stockwell TR, Liang W (2015) Mendelian randomisation meta-analysis sheds doubt on protective associations between 'moderate' alcohol consumption and coronary heart disease. Evid Based Med 20: 38. [crossref]

32. Holmes MV, Dale CE, Zuccolo L, et al. (2014) Association between alcohol and cardiovascular disease: Mendelian randomisation analysis based on individual participant data. BMJ 349: g4164. [crossref]

33. Mukamal KJ, Stampfer MJ, Rimm EB (2020) Genetic instrumental variable analysis: time to call mendelian randomization what it is. The example of alcohol and cardiovascular disease. Eur J Epidemiol 35: 93-97. [crossref]

34. Arbelaez A, Pajon A, Castillo M (2003) Acute Marchiafava-Bignami disease: MR findings in two patients. AJNR Am J Neuroradiol 24: 1955-1957. [crossref]

35. Linderborg K, Joly JP, Visapää JP, Salaspuro M (2008) Potential mechanism for Calvados-related oesophageal cancer. Food Chem Toxicol 46: 476-479. [crossref]

36. Morin Y, Daniel P (1967) Quebec beer-drinkers' cardiomyopathy: etiological considerations. Can Med Assoc J 97: 926-928. [crossref]
37. Brien SE, Ronksley PE, Turner BJ, Mukamal KJ, Ghali WA (2011) Effect of alcohol consumption on biological markers associated with risk of coronary heart disease: systematic review and meta-analysis of interventional studies. BMJ 342: $\mathrm{d} 636$.

38. Rohatgi A, Westerterp M, von Eckardstein A, Remaley A, Rye KA (2021) HDL in the 21st Century: A Multifunctional Roadmap for Future HDL Research. Circulation 143: 2293-2309. [crossref]

39. Knott CS, Britton A, Bell S (2018) Trajectories of alcohol consumption prior to the diagnosis of type 2 diabetes: a longitudinal case-cohort study. Int J Epidemiol 47: 953965. [crossref]

40. Goldberg IJ, Mosca L, Piano MR, Fisher EA (2001) Nutrition Committee, Council on Epidemiology and Prevention, and Council on Cardiovascular Nursing of the American Heart Association. AHA Science Advisory: Wine and your heart: a science advisory for healthcare professionals from the Nutrition Committee, Council on Epidemiology and Prevention, and Council on Cardiovascular Nursing of the American Heart Association. Circulation 103: 472-475. [crossref]

41. Mackness B, Mackness MI, Durrington PN, Arrol S, Evans AE, et al. (2000) Paraoxonase activity in two healthy populations with differing rates of coronary heart disease. Eur J Clin Invest 30: 4-10. [crossref]

42. Clarke R, Armitage J (2002) Antioxidant vitamins and risk of cardiovascular disease. Review of large-scale randomised trials. Cardiovasc Drugs Ther 16: 411-415. [crossref]

43. Galinski CN, Zwicker JI, Kennedy DR (2016) Revisiting the mechanistic basis of the French Paradox: Red wine inhibits the activity of protein disulfide isomerase in vitro. Thromb Res 137: 169-173. [crossref]

44. Goldberg DM, Yan J, Soleas GJ (2003) Absorption of three wine-related polyphenols in three different matrices by healthy subjects. Clin Biochem 36: 79-87. [crossref]

45. Piano MR (2017) Alcohol's Effects on the Cardiovascular System. Alcohol Res 38: 219-241. [crossref]

46. Tonelo D, Providência R, Gonçalves L (2013) Holiday heart syndrome revisited after 34 years. Arq Bras Cardiol 101: 183-189. [crossref]

47. Piano MR, Mazzuco A, Kang M, Phillips SA (2017) Cardiovascular Consequences of Binge Drinking: An Integrative Review with Implications for Advocacy, Policy, and Research. Alcohol Clin Exp Res 41: 487-496. [crossref]

48. Roerecke M, Kaczorowski J, Tobe SW, Gmel G, Hasan OSM, et al. (2017) The effect of a reduction in alcohol consumption on blood pressure: a systematic review and meta-analysis. Lancet Public Health 2: e108-e120.

49. Klein WMP, Jacobsen PB, Helzlsouer KJ (2020) Alcohol and Cancer Risk: Clinical and Research Implications. JAMA 323: 23-24. [crossref]

50. Ceylan-Isik AF, McBride SM, Ren J (2010) Sex difference in alcoholism: who is at a greater risk for development of alcoholic complication? Life Sci 87: 133-138. [crossref]

51. Jonas DE, Garbutt JC (2017) Screening and Counseling for Unhealthy Alcohol Use in Primary Care Settings. Med Clin North Am 101: 823-837. [crossref]

52. Kelly JF, Abry A, Ferri M, Humphreys K (2020) Alcoholics Anonymous and 12-Step Facilitation Treatments for Alcohol Use Disorder: A Distillation of a 2020 Cochrane Review for Clinicians and Policy Makers. Alcohol Alcohol 55: 641-651.

53. Alberg AJ, Shopland DR, Cummings KM (2014) The 2014 Surgeon General's report: commemorating the 50th Anniversary of the 1964 Report of the Advisory Committee to the US Surgeon General and updating the evidence on the health consequences of cigarette smoking. Am J Epidemiol 179: 403-412. [crossref]

54. Smoking and Health (1962) A report of the Royal College of Physicians. London: Pittman Medical Publishing Co.

55. Vardy J, Keliher T, Fisher J, Ritchie F, Bell C, et al. (2016) Quantifying alcohol-related emergency admissions in a UK tertiary referral hospital: a cross-sectional study of chronic alcohol dependency and acute alcohol intoxication. BMJ Open 6: e010005. [crossref]

56. Haider N (2013) Contesting Intoxication. Islamic Law and Society 20: 48-89.

57. Ruling on beer with $0.5 \%$ alcohol. https://www.islamweb.net/en/fatwa/299059/

\section{Citation:}

Durrington P, Soran H (2021) Alcohol and Health: Social Evolution, Production and Control. Internal Med Res Open J Volume 6(5): 1-8. 